\title{
Mitroflow pericardial aortic bioprosthesis in patients younger than 60 years
}

\author{
Charles A. Yankah, MD, PhD, Berlin, Germany
}

To date, the longest durability of pericardial aortic valves was found in 49- and 70-year-old patients in series reported by my colleagues and me, ${ }^{1,2}$ with explantation and death as end points: 22 and 22.75 years, respectively.

However, the clear disadvantage of bioprostheses is the propensity for failure in young patients as a result of structural valve deterioration (SVD), whereas pregnancy is not a factor for accelerated SVD. ${ }^{3}$ There is a changing role of pericardial bioprostheses in conjunction with mechanical prostheses in the treatment of heart valve disease in young patients because of morbidity associated with warfarin sodium (Coumadin) therapy and SVD..$^{1-4}$ This effect was examined in the context of younger patients, under 60 years, who received Mitroflow pericardial aortic valves (models 11 and 12; Sorin S.p.A., Saluggia, Italy) and have increased exposure to the risk of SVD and replacement.

\section{CLINICAL SUMMARY}

In early 2008, my colleagues and $\mathrm{I}^{2}$ reported our experience with 1513 patients, 89 under 60 years, who received Mitroflow pericardial aortic valves (models 11 and 12). Implantation of model 11 started in 1986 and of model 12 in 1996. The follow-up period for the evaluation was 1986 to 2007 . This brief communication comments on clinical experience with 104 patients ( 48 women and 56 men) who were younger than 60 years (median, $54.1 \pm 7.2$; range, $22-60$ years). Preoperative diagnoses were aortic valve incompetence $(\mathrm{n}=22)$, stenosis $(n=27)$, and combined lesions $(n=55)$. At a followup of 477.8 patient-years (median 4.0 years), the reoperation rate for SVD at 10 years was $7.7 \%$ at a linearized rate of $1.9 \%$ per patient-year (1.8 vs $2.2 \%$ per patient-year for Mitroflow models 11 and 12). Actuarial freedom from reoperation at 10 years was $72.5 \% \pm 8.2 \%$, and freedom from SVD for models 11 and 12 was $82 \%$ and $84 \%$, respectively $(P=.0714$; Figure 1). Actual risk of replacement for SVD at 10 years for both models was $12 \%$. Actuarial freedom from thromboembolism at 10 years was $96.5 \% \pm 2.1 \%$.

\footnotetext{
From Deutsches Herzzentrum Berlin, Germany.

Disclosures: None.

Received for publication Dec 22, 2009; revisions received June 24, 2010; accepted for publication July 3, 2010; available ahead of print Aug 16, 2010.

Address for reprints: Charles A. Yankah, MD, PhD, Deutsches Herzzentrum Berlin,

Augustenburger Platz 1, 13353 Berlin, Germany (E-mail: yankah@dhzb.de).

J Thorac Cardiovasc Surg 2010;140:e83-4

$0022-5223 / \$ 36.00$

Copyright $₫ 2010$ by The American Association for Thoracic Surgery

doi:10.1016/j.jtcvs.2010.07.015
}

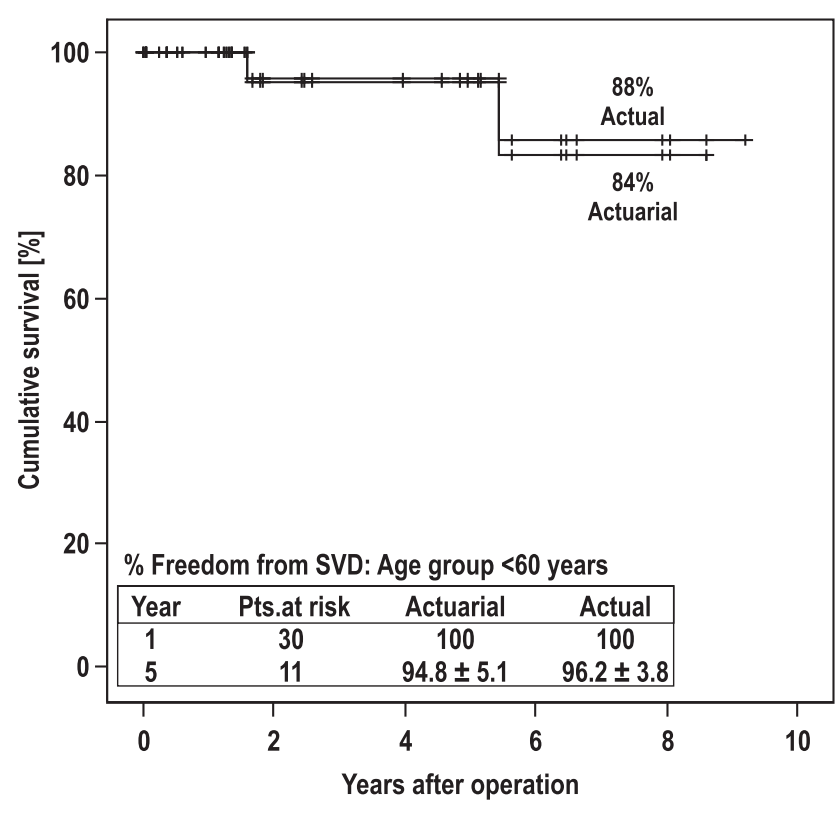

FIGURE 1. Actuarial and actual freedom from structural valve deterioration $(S V D)$ in patients under 60 years of age with Mitroflow pericardial aortic valve prosthesis (model 12).

\section{COMMENTS}

Durability of the Mitroflow pericardial valve in patients under 60 years at 18 years was $62 \%$ in comparison with $45 \%$ to $56 \%$ for porcine and allograft valves. ${ }^{2,4}$ In patients beyond 60 years the predicted probability of replacement of pericardial, porcine, and allograft valves before death revealed no significant differences. ${ }^{4}$ At rereplacement in our series, survival at 7 and 12 years in patients who reach the age of 60 to 69 years was $100 \%$, and it was $58 \%$ in patients older 70 years at 7 years. The data indicate that there is a survival advantage after recovery of myocardial function in patients who undergo a second valve operation. ${ }^{2}$ The Mitroflow pericardial aortic valve has also demonstrated durability of up to 22.75 years before explantation. ${ }^{2}$ Our data and reports of others throw light on the elusive and unsettled question of implantation of pericardial valves in patients under 60 years. ${ }^{1,2,4}$ In the light of these encouraging results, the Mitroflow pericardial aortic valve has demonstrated an important complementary role to allograft and pulmonary autografts if it is implanted in appropriately selected patients. ${ }^{4,5}$

\section{References}

1. Yankah CA, Weng Y, Meyer R, Siniawski H, Hetzer R. Twenty-two-year durability of Ionescu-Shiley pericardial aortic bioprosthesis implanted in a 49 -year-old 
woman: a valuable insight into the performance of current pericardial bioprostheses. J Thorac Cardiovasc Surg. 2006;132:427-8.

2. Yankah CA, Pasic M, Musci M, Stein J, Detschades C, Siniawski H, et al. Aortic valve replacement with the Mitroflow pericardial bioprosthesis: durability results up to 21 years. J Thorac Cardiovasc Surg. 2008;136:688-96.

3. Avila WS, Rossi EG, Grinberg M, Ramires JA. Influence of pregenancy after bioprosthetic valve replacement in young women: a prospective five-year study. J Heart Valve Dis. 2002;11:864-9.
4. Smedira NG, Blackstone EH, Roselli EE, Laffey CC, Cosgrove DM. Are allografts the biologic valve of choice for aortic valve replacement in nonelderly patients? Comparison of explantation for structural valve deterioration of allograft and pericardial prostheses. J Thorac Cardiovasc Surg. 2006; 131:558-64.

5. Klieverik LM, Takkenberg JJ, Bekkers JA, Roos-Hesselink JW, Witsenburg M, Bogers AJ. The Ross operation: a Trojan horse? Eur Heart J. 2007;28: 1993-2000. 